\title{
Seeds of n-GM Soybean Varieties Cultivated in Poland and Their Processing Products as High-Protein Feeds in Cattle Nutrition
}

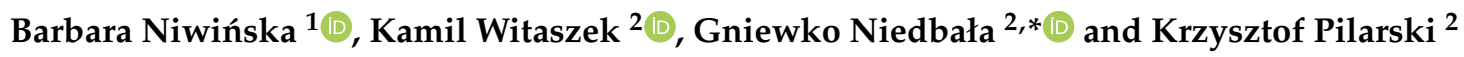 \\ 1 Department of Animal Nutrition and Feed Science, National Research Institute of Animal Production, \\ Krakowska 1, 32-083 Balice, Poland; barbara.niwinska@izoo.krakow.pl \\ 2 Faculty of Agronomy and Bioengineering, Institute of Biosystems Engineering, Poznań University of Life \\ Sciences, Wojska Polskiego 50, 60-627 Poznań, Poland; kamil.witaszek@up.poznan.pl (K.W.); \\ krzysztof.pilarski@up.poznan.pl (K.P.) \\ * Correspondence: gniewko@up.poznan.pl
}

Received: 10 March 2020; Accepted: 13 May 2020; Published: 15 May 2020

\begin{abstract}
Soybean (Glycine max (L.) Merr) is a source of high-quality edible protein and oil for humans, but also a high-quality feed in livestock feeding. In Poland, imported genetically modified soybean meal covers $65 \%$, and leguminous seeds that are cultivated locally cover $11 \%$ of the protein requirement in livestock nutrition. The implementation of the Polish national program and the European strategy supporting the growth of the leguminous area resulted in adaptation to local agro-climatic conditions of 36 varieties of non-genetically modified soybean (n-GM), which achieved an average seed yield of about $3.7 \mathrm{t} \cdot \mathrm{ha}^{-1}$ with a content of about $38 \%$ protein and $23 \%$ fat in dry matter. The 27-fold increase in n-GM soybean cultivation area observed over the past eight years resulted in the opportunities in the use of this high-protein feed in feeding cattle, the section providing $26 \%$ of gross agricultural production. In cattle feeding, soybean seeds are utilized as whole, cracked, roasted, and extruded full-fat seed; after oil pressing as cold press cakes and extruded oil cakes; and moreover, late-ripening soybean plants with late maturity are used as fodder plants. The presented review is based on literature and analysis of data on the use of each of these forms in cattle nutrition, including the limitation of their use as components of feed rations, which is caused by the high rate of nitrogen release in the rumen and the effects of fat and saponin on microbial fermentation in the rumen due to the role of endogenous seminal enzymes.
\end{abstract}

Keywords: soya; cattle nutrition; protein-rich feed; pre-treatment soybean

\section{Introduction}

Soybean (Glycine max (L.) Merr) is grown primarily for the production of grains due to the high content of protein (40\%) and oil (20\%) [1]. Soybean is an economically important leguminous plant used in feed industrial sectors as a source of the high-protein, defatted, and toasted soybean meal used in livestock feeding [2]. Most of the soybean meal imported into the EU is from genetically modified (GM) cultivars, and this product supplies $64 \%$ of the protein-rich feed materials [1,3]. In animal protein production, feeds account for $50 \%$ to $70 \%$ of costs, and the protein is the most expensive dietary component [4]. In Poland, imported GM soybean meal covered $65 \%$ of protein requirements in livestock nutrition in 2016 [5]. The cattle production (milk and slaughter animals) is an important section of agricultural production that provides $26 \%$ of gross agricultural production and during the last 15 years observed a threefold rise in the demand for protein feed which is related to $55 \%$ growth in milk production $[6,7]$. 
In recent years, agriculture is considered to be the main driver of losses of biodiversity and a major contributor to negative climate change and pollution [8]. The significant challenge in current livestock production is to minimize the threat of environmental pollution $[9,10]$. The most appropriate way to reduce the negative impact on the environment is to increase the area of legumes with high nitrogen binding efficiency and the abilities to improve the soil structure and enrich soil fertility [11]. Currently, legumes grown in Poland cover only $11 \%$ of the demand for feed protein in livestock nutrition [5]. With regard to sustainable development, the animal production sector, and ensuring farm profitability, the area of cultivation of new locally adapted legumes is growing. The most promising are soybean varieties, characterized by the high content in protein grains with a high nutritional value in animal nutrition [1]. On other hand, consumer concerns about genetically modified food production [12]. Public opinion poll results showed that about $57 \%$ of Polish citizens prefer food products of animal origin without the content or participation of genetically modified organisms (GMOs), and 65\% do not qualify them as safe once containing or produced with GMOs $[13,14]$. As a consequence of social acceptance for limiting the negative impact of animal production on the environment and improving the health safety of food of animal origin, during last 10 years, a 27-fold increase in the cropping area of varieties of non-genetically modified soybean (n-GM) was observed despite the cool growing conditions in Poland, belonging to the central climatic region of Europe [15]. In the structure of agricultural land in Poland, the percentage of farms qualified as small sections of arable land is $97.6 \%$ [16]. Small farms play an important role in supporting the employment of the rural community. They also play many key functions in the rural economy. Currently, there is a demand for the use of soybean obtained from own crops in feeding livestock. In order to be able to use soybean protein in animal nutrition, farmers need to know the appropriate agrotechnical procedures to produce high-quality soybeans [17].

Society accepts the implementation of agricultural practices that will limit climate change and pollution, increase the safety of food of animal origin, and also increase the usefulness of feeds derived from n-GM soybean varieties. In this review, we provide an update compiled from recent publications on the use soybean feed as: full-fat grain; cracked, roasted, or extruded full-fat grains; extruded oil cakes; and whole plant silage. Each of these products has unique nutritional properties, making them suitable for feeding specific categories of cattle.

\section{N-GM Soybean Varieties Cultivating in Poland}

Soybeans, faba beans, lupins, and peas are included in the group of arable crops with the agricultural name "legumes". All listed plant species belong to the family Fabaceae, and the basis for including them in the group is the ability to produce large seeds, rich in nutrients. Seeds of soybean are characterized by the highest content of protein with a high nutritional value in animal nutrition compared to others [1]. The protein is characterized by the nutritionally valuable amino acid composition, with a high content of the essential amino acid for animal feed and human food [18]. In addition, soybean plants are valuable from an agricultural point of view due to their ability to live symbiosis with rhizobial strain bacteria processing atmospheric nitrogen into organic compounds supplying both the plant and soil [19]. Moreover, an important agricultural feature of soybean plants is leaving rich crop residues that improve the physical and chemical properties of the soil [20].

The Center for Varietal Research in Poland, in accordance with the European Strategy in response to the growing interest in soybean cultivation, focused scientific work and applied research on the analysis of the possibilities of increasing the yield of this plant in agro-climatic conditions in Poland [21,22]. The implementation of the nationwide program "Center for Research on Protein Varieties Research Initiative" showed that the average seed yield of $36 \mathrm{n}-\mathrm{GM}$ soybean varieties was $3.7 \mathrm{t} \cdot \mathrm{ha}^{-1}$, the protein yield was close to $1200 \mathrm{~kg} \cdot \mathrm{ha}^{-1}$, and seeds contained an average of $38.3 \%$ protein and $22.8 \%$ fat in dry matter [23]. The area of soybean cultivation increased; in 2010, it was 0.2 thousand ha; eight years later, soybean was cultivated on 5.4 thousand ha, and seed harvest reached 10.4 thousand tons [15]. The best-yielding varieties are presented in Table 1. 
Table 1. Seeds chemical composition of non-genetically modified (n-GM) soybean varieties with the highest seed crude protein yield ( $\geq 1.0$ ton/hectare), achieving harvest maturity in agro-climatic conditions of Poland in 2018 [23].

\begin{tabular}{|c|c|c|c|c|c|c|c|}
\hline \multirow{2}{*}{$\begin{array}{l}\text { Soybean } \\
\text { Variety }\end{array}$} & \multicolumn{3}{|c|}{$\begin{array}{c}\text { Content } \\
\text { (\% in Dry Matter) }\end{array}$} & \multicolumn{2}{|c|}{$\begin{array}{c}\text { Yield } \\
\text { (ton/ha) }\end{array}$} & \multirow{2}{*}{$\begin{array}{c}\text { Maturity } \\
\text { Groups } \\
\text { Qualification }\end{array}$} & \multirow{2}{*}{$\begin{array}{l}\text { Vegetation } \\
\text { Length } \\
\text { (Days) }\end{array}$} \\
\hline & $\begin{array}{l}\text { Crude } \\
\text { Protein }\end{array}$ & Crude Fat & $\begin{array}{l}\text { Crude } \\
\text { Fiber }\end{array}$ & Seed & $\begin{array}{l}\text { Crude } \\
\text { Protein }\end{array}$ & & \\
\hline $\begin{array}{c}\mathrm{ES}^{1} \\
\text { Comandor }\end{array}$ & 39.2 & 22.0 & 7.1 & 4.3 & 1.3 & Late & 133 \\
\hline Coraline & 38.3 & 23.3 & 8.2 & 4.2 & 1.3 & Very late & 141 \\
\hline Abelina & 38.1 & 23.6 & 9.0 & 4.1 & 1.2 & Medium late & 129 \\
\hline Aligator & 37.2 & 23.7 & 7.5 & 4.1 & 1.2 & Late & 134 \\
\hline Erica & 38.4 & 23.1 & 7.7 & 3.9 & 1.1 & Early & 123 \\
\hline Augusta & 38.5 & 21.9 & 7.2 & 3.1 & 1.0 & Very early & 121 \\
\hline Maja & 39.8 & 23.6 & 7.8 & 3.0 & 1.0 & Medium early & 131 \\
\hline
\end{tabular}

The differences between varieties and between raw or processed products of soybean in terms of quantity and quality of nutrients affect their usefulness in their usefulness in meeting livestock nutritional requirements [24,25]. In the context of environment protection and reducing the negative impact of modern agriculture on the food security and effective replacement of well-calibrated and chemically stable imported GM soybean meal, the inclusion of n-GM soybean varieties and processing products in cattle nutrition requires information on the possibilities of their proper use.

\section{The Factors Affecting Soybean Utilization in Cattle Nutrition}

Due to the high content of protein and fat, soybean seeds are a valuable high-protein and high-energy feed in cattle feeding. In ruminants, the nutritional value of protein is measured by the amount of amino acids absorbed in the small intestine from two fractions: the microbial protein synthetized in the rumen from the available nitrogen and energy (fraction estimated by the rumen microbial digestion coefficient) and the dietary protein which escaped digestion in the rumen (fraction determined by the intestinal digestion coefficient) [26]. The efficiency of microbial protein synthesis in the rumen depends on the precise and adequately selection of feed ration components, ensuring synchronization of the rate of nitrogen and energy release in the rumen fermentation processes [27]. The coefficient of rumen microbial protein digestion of raw soybean seeds reaching a high value of 0.72 indicated a high rate of nitrogen release [28]. The intense digestion of feed protein in the rumen could result in nitrogen losses in the form of urea in urine and ammonia in gases.

The estimation of the feed energy value included the fat content [26]. In the rumen environment, two major processes occur during the feed fat metabolism: the hydrolysis of ester linkages in lipids liberated free fatty acids and the biohydrogenation of unsaturated fatty acids [29]. Unsaturated fatty acids constitute nearly $88 \%$ of the soybeans oil [30]. The fat increases the energy density of diets to meet requirements of high producing dairy cows, but a large amount in the ration of soybean fat negatively affects the rumen fermentation due to the toxic nature of unsaturated fatty acids to many rumen bacteria [29]. The fat content in the ration for adult cattle should not exceed $7 \%$ of the dry matter and will usually be adequate at $6 \%$ or less [31].

The use of soybean seeds in feed ration composition is limited by the constituents modifying digestion in animal alimentary tract. Soybean plants contain trypsin and chymotrypsin inhibitors, lectins, antigenic proteins, estrogens, saponins, phytic acid, and non-starch polysaccharides which are referred to as anti-nutritional factors exerting negative impacts on monogastric and immature ruminant animal feeding $[32,33]$. In adult ruminants, most of the harmful anti-nutrient substances are 
effectively inactivated by bacteria, fungi, and protozoa inhabiting the mature rumen, but saponins are not detoxified [34]. Saponins are a diverse group of glycosides, and their content in the seed hypocotyl of soybean seeds ranges from $0.6-6.2 \%$ [35]. The primary effect of saponins is the removal of protozoa from the microbial ecosystem in the rumen (defaunation), followed by a significant increase in the number of cellulolytic and total bacterial numbers in the rumen, which on the one hand causes intensive degradation of protein feed, but also increases the efficiency of microbial protein synthesis and the supply of protein to the duodenum [34]. Depending on the dose of saponins, a reduction in methane emissions was observed as an effect of decreasing the activities and numbers of methanogens [36]. In calves younger than 3 months, soybean seed protein is qualified as immunoreactive and escapes digestion [32]. The 70\% of storage are classified as $\beta$-conglycinin (7S) and glycinin (11S) proteins [37-39]. The immunoreactive proteins in the functional rumen are inactivate [32].

Additional factors limiting the use of soybean seeds as a component of feed ration for cattle are endogenous seed enzymes, lipases, lipoxygenases, and urease. Lipases catalyze the hydrolysis of ester-carboxylic bonds of oil triacylglycerols and release fatty acids, while lipoxygenases catalyze the oxidation of unsaturated bonds to form hydroperoxides of the corresponding fatty acids $[40,41]$. The urease enzyme in the presence of urea in the ration achieves high hydrolytic activity leading to rapid ammonia production [42].

The high rate of nitrogen release in the rumen, the modification effect of fat and saponins on rumen fermentation, and the activity of endogenous seed enzymes are factors that require attention in the proper use of soybean in cattle nutrition.

\section{The Application of Raw Seeds and Their Processing Products in Cattle Feeding}

In the structure of agricultural land in Poland, the percentage of farms qualified as small with an area of $\leq 50$ ha of arable land is $97.6 \%$; the total number of agricultural holdings and farms with an area of $\leq 5$ ha is $53.3 \%$ [16]. The structure of arable land in Poland does not provide the homogeneous material for companies producing high-protein feed. At present, the owners of small farms are interested in increasing the cultivation area of soybean varieties adapted to Polish agro-climate conditions both to reduce climate change and pollution and increase the safety of food of animal origin, as well as because of the increase in economic profitability. In the years 2014-2015, the percentage of revenues in total soybean cultivation costs reached $98 \%$ [43]. Economic efficiency is supported by EU subsidies, which covered $60 \%$ of the costs incurred by farmers for the cultivation of legumes [44].

Currently, an essential factor in the efficient use of n-GM soybean is the information on the proper use of raw seeds and the application of technological processes extending their utilization in feeding various technological groups of cattle. Processing of soybean seeds and whole soy plants in small farms into soybean products for feeding cattle are presented on Figure 1.

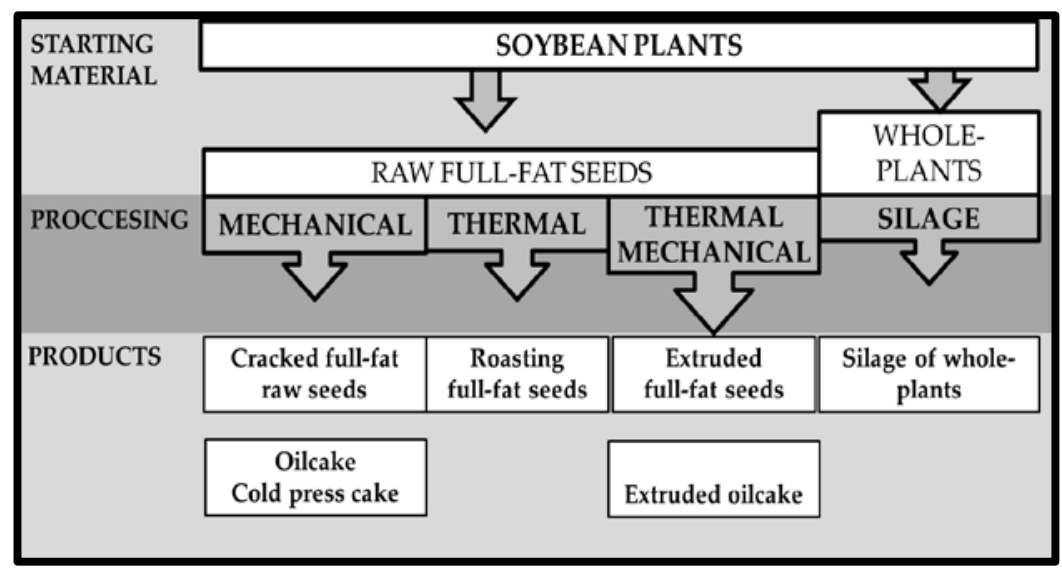

Figure 1. Processing of soybean seeds and whole soy plants into soybean products for feeding cattle on small farms. 
The supply of protein to increase the protein content of rations is one of the most important feeding costs on high yielding cattle farms. The high rate of protein microbial digestion in the rumen indicates the need for use the processing technologies to reduce this susceptibility. The effects of processing methods on the digestibility of protein in cattle digestive tract is presented on Table 2.

Table 2. The effects of processing methods of soybean on the digestibility of protein in cattle alimentary tract.

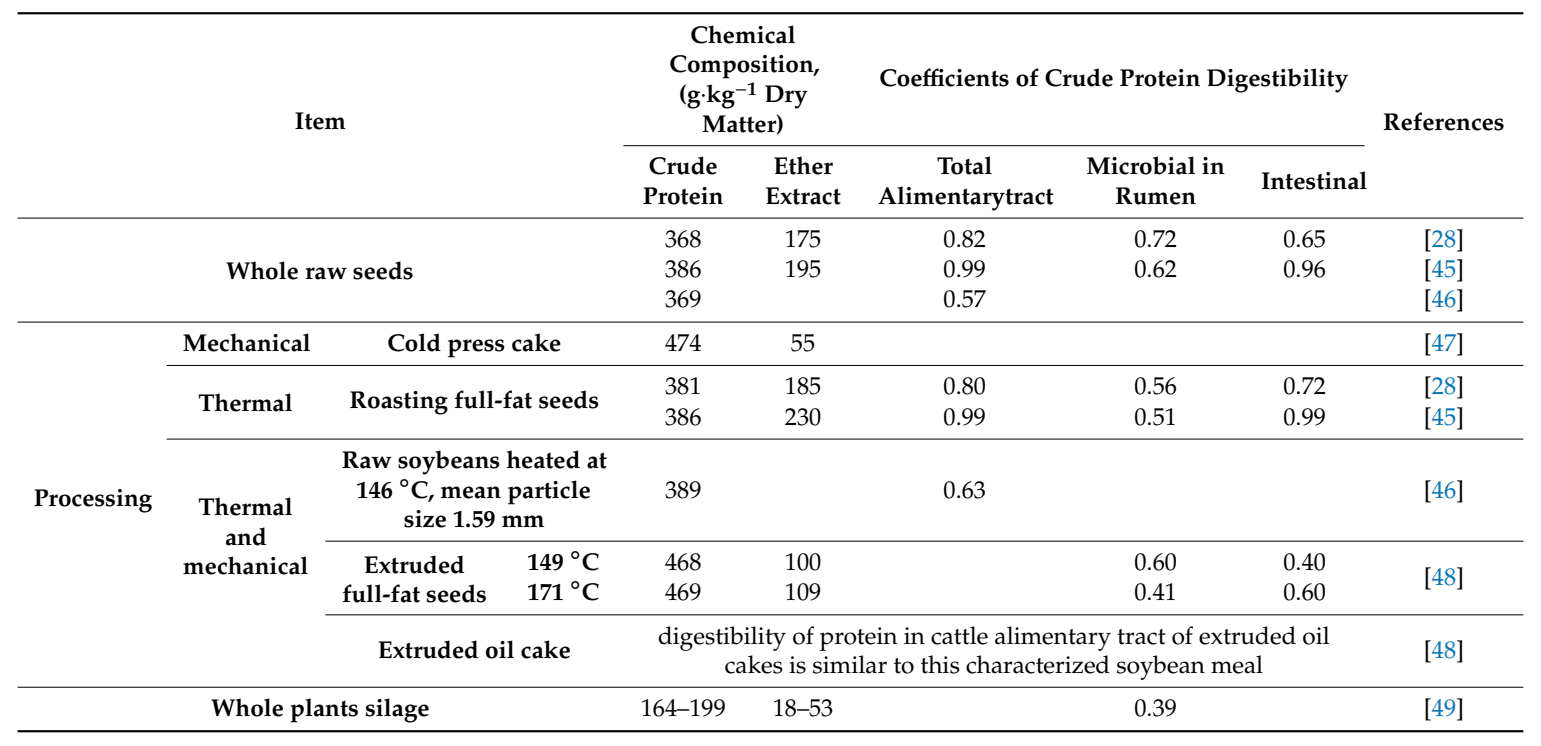

Numerous scientific reports confirm the usefulness of the application of raw seeds and their processing products in cattle feeding. The effects of inclusion of raw soybean seeds, their processing products, and soybean forage in ration on performance in dairy cows are presented in Table 3.

Below, a brief overview of science reports of the use raw soybean seeds, their processing products, and soybean forage in cattle nutrition is presented. 
Table 3. Effects of raw soybean seeds, their processing products, and soybean forage inclusion in ration on performance in dairy cows.

\begin{tabular}{|c|c|c|c|c|c|c|c|}
\hline \multicolumn{3}{|c|}{ Item } & Feeding Period & Milk Yield (kg/d) & $\begin{array}{c}\text { Inclusion Level } \\
\text { (\% in Ration Dry Matter) }\end{array}$ & Productive Performance Effects & References \\
\hline & \multirow{4}{*}{\multicolumn{2}{|c|}{ Whole raw seeds }} & $\begin{array}{l}90,60,30,0 \mathrm{~d} \text { relative to the } \\
\text { calving- } 84 \mathrm{~d} \text { of lactation }\end{array}$ & 30.1 & 12 & $\begin{array}{c}\text { no effects on: } \\
\text { milk yield, } \\
\text { milk composition compared with } \\
\text { control fed without raw soybean }\end{array}$ & {$[50]$} \\
\hline & & & mid- to late lactation & & $0,9,18$, or 27 & $\begin{array}{l}\text { milk yield, lactose, and protein yield decreased, fat } \\
\text { and unsaturated fatty acids increased }\end{array}$ & [51] \\
\hline & & & $188-201 \mathrm{~d}$ of lactation & $18.9 \pm 3.2$ & 16 & $\begin{array}{c}\text { no effects on: } \\
\text { milk yield, } \\
\text { milk composition compare with } \\
\text { control fed without raw soybean }\end{array}$ & [52] \\
\hline & & & $121-145 \mathrm{~d}$ & 30.2 & 20 & $\begin{array}{l}\text { milk yield and milk composition not differ compare } \\
\text { with control fed without raw soybean }\end{array}$ & [53] \\
\hline \multirow{5}{*}{ Processing } & \multirow[t]{2}{*}{ Mechanical } & $\begin{array}{l}\text { Cracked, particle } \\
\text { size } 2 \text { or } 4 \mathrm{~mm}\end{array}$ & & & 20 & $\begin{array}{c}\text { no effects treatment on: } \\
\text { milk yield } \\
\text { milk composition }\end{array}$ & [53] \\
\hline & & Cold press cake & $15-71 \mathrm{~d}$ of lactation & $32-35$ & $0,6,12$, or 18 & $\begin{array}{l}\text { no effects of treatment on: } \\
\text { milk protein, } \\
\text { milk fat, } \\
\text { energy-corrected milk yield }\end{array}$ & [47] \\
\hline & Thermal & $\begin{array}{l}\text { Roasting full-fat } \\
\text { seeds }\end{array}$ & \multicolumn{5}{|c|}{ no data available } \\
\hline & \multirow{2}{*}{$\begin{array}{l}\text { Thermal and } \\
\text { mechanical }\end{array}$} & $\begin{array}{l}\text { Extruded full-fat } \\
\text { seeds }\end{array}$ & $141169 \mathrm{~d}$ of lactation & 41 & 13 & $\begin{array}{l}\text { substituting soybean meal with extruded full-fat } \\
\text { seeds improved feed intake and milk yield }\end{array}$ & [48] \\
\hline & & Extruded oil cake & nutritional value $o$ & extruded oil cakes a & d the range of use in feedin & cattle are similar to those of soybean meal & [48] \\
\hline \multicolumn{3}{|c|}{ Whole plants silage } & early to mid-lactation & $35-37$ & 35 & $\begin{array}{l}\text { no effects on energy-corrected milk yield, } \\
\text { milk composition relative to alfalfa silage }\end{array}$ & {$[54]$} \\
\hline
\end{tabular}




\subsection{Whole Full-Fat Raw Soybean Seeds}

The whole full-fat raw soybean seeds are used as a component of the daily ration for heifers and beef cattle. The heifers achieved a $900 \mathrm{~g} \cdot \mathrm{d}^{-1}$ weight gain at 12 months of age when fed rations with $20 \%$ raw whole soybeans [55]. The Angus steers received $1.26 \mathrm{~kg} \mathrm{DM} \cdot \mathrm{d}^{-1}$ of raw whole soybeans supplementing low-to-medium quality roughages as the basal diet, achieving the expected $700 \mathrm{~g} \cdot \mathrm{d}^{-1}$ weight gain [56].

Research results indicate that the amount of whole raw full-fat soybean seeds in the feed ration for high producing dairy cows depended of the stage of lactation. A $12 \%$ content in the feed ration given to cows from the 90th day preceding the expected date of calving to the 81st day of lactation had no effects on their energy-corrected milk yield and composition and positively affected the immunity of cows compared with those fed without raw soybean [50]. The whole full-fat raw bean content reaches $16 \%$ of the feed ration when used in feeding cows during days 188-201 of lactation (the ration contained $5.7 \%$ fat) without negative effects on the dry matter intake and production and composition of milk [52]. The content of this feed in the ration for adult cattle is limited by the amount of fat contained in the feed ration [31]. Venturelli et al. [51] added increasing levels of whole raw soybean $(0 \%, 9 \%, 18 \%$, and $27 \%)$ in the diet of mid- to late-lactating cows and reported a linear decrease of milk yield and linear increase of fat and unsaturated fatty acids content. The current research results indicate, that feeding cows with soybean seeds in the form of whole seeds ensures protection of unsaturated fatty acids against rumen biohydrogenation; this protection is more effective than the administration of fatty acids in the form of calcium salts [52,57]. The results presented above suggest that the inclusion of $12 \%$ of whole full-fat raw soybean seeds in daily ration during the first period of lactation and $16 \%$ during the late period did not adversely affect the production performance of dairy cows, while higher levels during mid-lactation reduced milk yield.

\subsection{Mechanical Processing Products}

Mechanical processing increases the intensity of microbial degradation of the total protein as well as the rate of fat release and biohydrogenation in the rumen environment. The prepared feed has a short shelf life because during storage, fat is susceptible to fat-modifying processes resulting from the activity of endogenous enzymes, storage duration, and temperature which influenced the content and composition of fatty acids in raw soybean [58].

\subsubsection{Cracked Full-Fat Raw Seeds}

Cracked full-fat raw soybeans are applied in cattle nutrition. Cracking soybean in small particles causes the protein content to be more rapidly degraded than the protein in larger particles because small particles have a larger surface area [46]. The latest research from 2015 showed that inclusion of $200 \mathrm{~g}$ per kg ration (dry matter) of whole full-fat raw seeds and seeds cracked to particle size 2 or $4 \mathrm{~mm}$ stated that milk yield and milk composition were not influenced by experimental diets [53].

\subsubsection{Cold Press Cake}

The mechanical process, which is a crusher, is a commonly used method of oil and cake production. This process is mainly used in the feed industry. Mechanical pressing of oil is often combined with extrusion to increase productivity [59]. The process itself is the physical pressure that the soybeans undergo for oil extraction. If the temperature does not exceed $49^{\circ} \mathrm{C}$, the process is referred to as "cold pressing", and the oil has a high nutritional value in human nutrition. The resulting oil cake has a lower fat content and higher protein content compared to raw seeds, while the activity of endogenous enzymes does not change. Cold press cake in the feeding of dairy cows during the first period of lactation (32-35 kg. $\mathrm{d}^{-1}$ mean milk production) was introduced at the level of $6 \%, 12 \%$, and $18 \%$ of ration (dry matter) for cows [47]. The author observed that milk protein, milk fat, energy-corrected milk yield, and feed efficiency did not differ between treatments and the control group fed soybean meal. 


\subsection{Thermal Treatment Processing Products}

Heat treatment (steam explosion) can increase the degradation of lignin, cellulose, and hemicellulose in by-products from the milling industry. This will make the by-products more suitable for ruminants [60]. However, the most important effect of thermal treatment is limitation of protein solubility in the rumen and increasing the pool of available protein in the small intestine. The decrease in soybean protein susceptibility to rumen microbial degradation results from heat-initiated chemical reactions between free amino acid groups of the peptide chain and sugar aldehyde groups of carbohydrates $[45,46]$. It was investigated that seeds heated to a temperature of $140-145^{\circ} \mathrm{C}$ increased the proportion of the non-degradable protein fraction in the rumen in relation to raw seeds by $26 \%$, the proportion of this fraction in heated seeds was $56 \%$; heating increased the amount of digestible protein in the small intestine by $18 \%$ from the non-degradable fraction in the rumen [28]. Additionally, an inactivation of endogenous seed enzymes is a beneficial effect of thermal treatments. It has been shown that temperature above $50^{\circ} \mathrm{C}$ inactivates lipoxidase and above $80^{\circ} \mathrm{C}$ denatures urease $[61,62]$. Roasting and extrusion are the most commonly used types of thermal heating.

\section{Roasted Full-Fat Soybean Seeds}

Positive roasting effects are characterized by limitation of protein solubility in the rumen and inactivation of endogenous grain enzymes. The limitation of the product's share in the composition of feed ration results from the high fat content and possible fragmentation of seeds. The results presented by Rafiee-Yarandi et al. [63] showed that roasting at $115^{\circ} \mathrm{C}$ for $10 \mathrm{~min}$ of full-fat soybeans crushed to a particle size of $1.15 \mathrm{~mm}$ preferably stabilizes the ratio of non-degradable protein content in the rumen to digestible protein in the small intestine, ensuring optimal protein nutritional values of such processed full-fat soybeans in cattle feeding. According to Tice [64], roasting of raw soybean seeds resulted in an increase of unsaturated fatty acids content in milk fat; additionally, the content of polyunsaturated fatty acids in milk increased compared to milk from cows fed with raw soybeans. These results are in line with Salles et al. [65] who indicated that the inclusion of unsaturated vegetable oils in the diet of lactating dairy cows significantly increased the content of unsaturated fatty acids in milk.

\subsection{Thermal and Mechanical Processing Products}

The extrusion parameters are high temperature and pressure which have a large influence on the properties of the extrudate. The process involves exposure to fluctuations of these factors. Positive effects are the limitation of protein solubility in the rumen and inactivation of endogenous seeds enzymes. Negative effects are fragmentation of seeds and rupture of fatty micelles during a rapid pressure drop when the product leaves the extruder. Disruption of fatty micelles causes a rapid release of oil directly into the rumen after administering feed with the presence of extruded full-fat soybeans [66].

\subsubsection{Extruded Full-Fat Soybean Seeds}

Extruded full-fat soybeans are characterized by high protein and energy values. The product is used in feeding dairy cows, especially in the early lactation period. The introduction of $7.2 \%$ of extruded full-fat soy (about $1.5 \mathrm{~kg}$ ) in the composition of the feeding ration during the first 4 weeks of lactation had a positive effect on cows metabolic indicators and milk production in the first 8 weeks of lactation [67]. Moreover, iso-protein replacement of $13 \%$ soybean meal with extruded full-fat soybeans in the composition of a completely mixed ration with a fat content of $4.35 \%$ had a positive effect on feed intake and milk yield of cows without affecting milk composition [48]. Similar effects were obtained by introducing full-fat extruded soybeans in place of soybean meal to the feed ration administered up to 60 days of lactation period [68]. Extruded full-fat soybeans are also used in calf nutrition. It was investigated that replacing $50 \%$ of the soybean meal by the Extruded full-fat soybean seeds in the starter mix composition did not reduce weight gain and efficiency of feed utilization on the obtained growth $[69,70]$. 


\subsubsection{Extruded Oil Cake}

The nutritional value of extruded oil cakes and the range of use in feeding cattle are similar to those characterized soybean meal [48].

\subsection{Whole-Plant Soybean}

Soybean was introduced to Western countries as a forage crop, and some forage soybean cultivars have been released [71]. A narrow margin is the use of whole plants of varieties with late maturity, the seeds of which may not reach maturity in unfavorable weather conditions. In Eastern Canada and the Northern United States, soybean cultivars have been developed specifically for use as a forage crop. Dry matter yields of forage cultivars range between 4.5 and $14 \mathrm{t} \cdot \mathrm{ha}^{-1}$ [72]. The nutritional value of silage is affected by the vegetative development phase of the plant, drying time, chemical composition of the silage and the composition of the feed ration modifying digestion in the rumen [49]. Advancing plant maturity increased the crude protein and ether content from 164 to 199 and from 18 to $53 \mathrm{~g} \cdot \mathrm{kg}^{-1}$ DM [72]. As Vargas-Bello-Pérez et al. [54] stated, the energy-corrected milk yield and milk chemical composition was the same in dairy cows fed with alfalfa silage and those fed with whole-plant soybean silage. In Poland, no research has been carried out on the cultivation of soybean plants of late-ripening varieties intended for the production of forage crop.

\section{Conclusions}

Society in Poland expects the implementation of agricultural practices that will limit climate change and pollution and increase the safety of food of animal origin. An increase in acreage of non-genetically modified soybean (Glycine max (L.) Merr), included in legumes, was observed during the last years to meet these expectations. The Polish national program and the European strategy supporting the growth of the leguminous area resulted in adaptation to local agro-climatic conditions of varieties, characterized by high yield of seeds, protein, and fat.

A review of the literature showed that soybean crops can be used in feeding cattle in many forms as raw seeds and their thermally and/or mechanically processed products, each of which has unique nutritional properties and limitations. The raw soybean seeds protein is characterized by a high rate of nitrogen release in the rumen as indicated by the 0.72 value of efficiency of the rumen microbial digestion coefficient, and inadequate feed ration composition could result in nitrogen losses. The decrease in protein susceptibility to rumen microbial degradation results from thermal processing, as roasting and extrusion decrease the rumen microbial digestion coefficient to 0.51 and 0.41 (respectively). The fat is characterized by a high content of unsaturated fatty acids toxic to many rumen bacteria, and a high fat content in the ration negatively affects the rumen fermentation. The decrease in fat content results from mechanical processing. The mechanical processing increasing fragmentation of seeds with a larger surface area causes the more rapid protein microbial digestion in the rumen. On the other hand, mechanical processing in which physical pressure is associated with growth of temperature leads to the lowering of the rate of rumen microbial digestion. The combination of thermal and mechanical processing is extrusion, with high temperature and pressure changes. In extruded oil cake, protein solubility in the rumen is limited, but in extruded full-fat soybean products, disruption of fatty micelles causes a rapid release of oil directly into the rumen.

The successful implementation of locally cultivated varieties of soybean, whole plants, their raw seeds, and their processing products in feeding cattle depends on the precise and adequate selection of feed ration components, ensuring synchronization of the rate of nitrogen and energy release in the rumen fermentation processes. 
Author Contributions: Conceptualization, B.N. and K.W.; methodology, B.N. and K.W.; validation, B.N., K.W. and G.N.; formal analysis, G.N.; investigation, B.N. and K.W.; resources, B.N., K.W., G.N. and K.P.; data curation, B.N., K.W. and G.N.; writing—original draft preparation, B.N. and K.W.; writing-review and editing, B.N., K.W., G.N. and K.P.; visualization, B.N. and K.W.; supervision, B.N., K.W. and G.N.; project administration, B.N. and K.W.; funding acquisition, K.W. and G.N. All authors have read and agreed to the published version of the manuscript.

Acknowledgments: The publication was co-financed within the framework of Ministry of Science and Higher Education program as "Regional Initiative Excellence" in years 2019-2022, Project No. 005/RID/2018/19.

Conflicts of Interest: The authors declare no conflict of interest. The funders had no role in the design of the study; in the collection, analyses, or interpretation of data; in the writing of the manuscript, or in the decision to publish the results.

\section{References}

1. De Visser, C.L.M.; Schreuder, R.; Stoddard, F. The EU's dependency on soya bean import for the animal feed industry and potential for EU produced alternatives. OCL 2014, 21, D407. [CrossRef]

2. Stein, H.H.; Berger, L.L.; Drackley, J.K.; Fahey, G.C., Jr.; Hernot, D.C.; Parsons, C.M. Nutritional properties and feeding values of soybeans and their co-products. In Soybeans, Chemistry, Production, Processing, and Utilization; Johnson, L.A., White, P.J., Galloway, R., Eds.; AOCS Press: Urbana, IL, USA, 2008; pp. 613-660.

3. Ronald, P. Plant Genetics, Sustainable Agriculture and Global Food Security. Genetics 2011, 188, 11-20. [CrossRef] [PubMed]

4. Flachowsky, G.; Meyer, U. Challenges for Plant Breeders from the View of Animal Nutrition. Agriculture 2015, 5, 1252-1276. [CrossRef]

5. Dzwonkowski, W.; Rola, K.; Hanczakowska, E.; Niwińska, B.; Światkiewicz, S. Economic Aspects of Replacing GM Soybeans by Protein Feed Crops Grown in Poland; Institute of Agricultural and Food Economics-National Research Institute: Warsaw, Poland, 2016; ISBN 978-83-7658-656-4. (In Polish)

6. Statistical Yearbook of the Republic of Poland; Central Statistical Office, Ministry of National Education for School Libraries: Warsaw, Poland, 2019.

7. Dzwonkowski, W.; Rola, K.; Hanczakowska, E.; Niwińska, B.; Światkiewicz, S. Report on the Situation on the Global GMO Plant Market and Possibilities of Genetically Modified Soybean Substitution with Domestic Protein Crops in Terms of Feed Balance; Institute of Agricultural and Food Economics-National Research Institute: Warsaw, Poland, 2015; ISBN 978-83-7658-569-7. (In Polish)

8. Bajželj, B.; Richards, K.S.; Allwood, J.M.; Smith, P.; Dennis, J.S.; Curmi, E.; Gilligan, C.A. Importance of food-demand management for climate mitigation. Nat. Clim. Chang. 2014, 4, 924-929. [CrossRef]

9. Mutsvangwa, T.; Davies, K.L.; McKinnon, J.J.; Christensen, D.A. Effects of dietary crude protein and rumen-degradable protein concentrations on urea recycling, nitrogen balance, omasal nutrient flow, and milk production in dairy cows. J. Dairy Sci. 2016, 99, 6298-6310. [CrossRef]

10. Britt, J.H.; Cushman, R.A.; Dechow, C.D.; Dobson, H.; Humblot, P.; Hutjens, M.F.; Jones, G.A.; Ruegg, P.S.; Sheldon, I.M.; Stevenson, J.S. Invited review: Learning from the future-A vision for dairy farms and cows in 2067. J. Dairy Sci. 2018, 101, 3722-3741. [CrossRef]

11. Wang, D.; Yang, S.; Tang, F.; Zhu, H. Symbiosis specificity in the legume-Rhizobial mutualism. Cell. Microbiol. 2012, 14, 334-342. [CrossRef]

12. Maghari, B.M.; Ardekani, A.M. Genetically modified foods and social concerns. Avicenna J. Med. Biotechnol. 2011, 3, 109-117.

13. Labeling GMO-Free Food-A Proposal for Poland. Institute of Civil Affairs. Federation of Greens-Krakow Group (In Polish). Available online: https://chcewiedziec.pl/przerwij-eksperyment/press/raport_Chce_ wiedziec.pdf (accessed on 1 February 2020).

14. Poles on Food Safety and GMOs. Public Opinion Research Center: Warsaw, Poland, BS/2/2013; Available online: https://www.cbos.pl/SPISKOM.POL/2013/K_002_13.PDF (accessed on 1 February 2020).

15. Eurostat. Crop Production in EU Standard Humidity. Available online: https://appsso.eurostat.ec.europa.eu/ nui/submitViewTableActiondo (accessed on 22 August 2019).

16. Agriculture 2018 (2019); Statistics Poland, Agriculture Department: Warsaw, Poland, 2019.

17. Bellaloui, N.; McClure, A.M.; Mengistu, A.; Abbas, H.K. The Influence of Agricultural Practices, the Environment, and Cultivar Differences on Soybean Seed Protein, Oil, Sugars, and Amino Acids. Plants 2020, 9, 378. [CrossRef] 
18. Fallen, B.D.; Hatcher, C.N.; Allen, F.L.; Kopsell, D.A.; Saxton, A.M.; Chen, P.; Kantartzi, S.K.; Cregan, P.B.; Hyten, D.L.; Pantalone, V.R. Soybean Seed Amino Acid Content QTL Detected Using the Universal Soy Linkage Panel 1.0 with 1,536 SNPs. Plant Genet. Genomics Biotechnol. 2017, 1, 68-79. [CrossRef]

19. Wang, Q.; Liu, J.; Zhu, H. Genetic and Molecular Mechanisms Underlying Symbiotic Specificity in Legume-Rhizobium Interactions. Front. Plant Sci. 2018, 9, 313. [CrossRef] [PubMed]

20. Stagnari, F.; Maggio, A.; Galieni, A.; Pisante, M. Multiple benefits of legumes for agriculture sustainability: An overview. Chem. Biol. Technol. Agric. 2017, 4, 2. [CrossRef]

21. Program on Activities in the Field of Obtaining Alternative Protein Sources for GM Soy Protein in Animal Nutrition from 26 March 2018. Ministry of Agriculture and Rural Development of the Republic of Poland: Warsaw, Poland, (In Polish). Available online: https://www.senat.gov.pl/gfx/senat/userfiles/_public/k9/ komisje/2018/krrw/materialy/program98pos.pdf (accessed on 1 February 2020).

22. 2017/2116(INI). European Strategy for the Promotion of Protein Crops-Encouraging the Production of Protein and Leguminous Plants in the European Agriculture Sector. Available online: https://www.europarl. europa.eu/doceo/document/A-8-2018-0121_EN.html (accessed on 1 February 2020).

23. Results of Post-Registration Varietal Experiments. Beans and Soybeans 2018. Research Centre for Cultivar Testing in Poland. Publication no 150. 22/2019, 350. Available online: http://www.coboru.pl/Publikacje_ COBORU/Wyniki_PDO/WPDO_Bobowate_2018.pdf (accessed on 1 February 2020).

24. Gu, C.; Pan, H.; Sun, Z.; Qin, G. Effect of Soybean Variety on Anti-Nutritional Factors Content, and Growth Performance and Nutrients Metabolism in Rat. Int. J. Mol. Sci. 2010, 11, 1048-1056. [CrossRef] [PubMed]

25. Palacios, M.F.; Easter, R.A.; Soltwedel, K.T.; Parsons, C.M.; Douglas, M.W.; Hymowitz, T.; Pettigrew, J.E. Effect of soybean variety and processing on growth performance of young chicks and pigs. J. Anim. Sci. 2004, 82, 1108-1114. [CrossRef]

26. Strzetelski, J.A.; Brzóska, F.; Kowalski, Z.M.; Osięgłowski, S. Feeding Recommendations for Ruminants and Feed Nutrition Tables; The National Research Institute of Animal Production: Cracow, Poland, 2014; ISBN 978-83-938377-0-0.

27. Sinclair, L.A.; Garnsworth, P.C.; Newbold, J.R.; Buttery, P.J. Effect of synchronizing the rate of dietary energy and nitrogen release on rumen fermentation and microbial protein synthesis in sheep. J. Agric. Sci. 1993, 120, 251-263. [CrossRef]

28. Nasri, M.H.F.; France, J.; Danesh Mesgaran, M.; Kebreab, E. Effect of heat processing on ruminal degradability and intestinal disappearance of nitrogen and amino acids in Iranian whole soybean. Livest. Sci. 2008, 113, 43-51. [CrossRef]

29. Lock, A.L.; Harvatine, K.J.; Drackley, J.K.; Bauman, D.E. Concepts in Fat and Fatty Acid Digestion in Ruminants. In Proceedings of the Intermountain Nutrition Conference; Utah State University: Logan, UT, USA, 2006; pp. 85-100.

30. Sultan, S.M.; Dikshit, N.; Vaidya, U.J. Oil content and fatty acid composition of soybean (Glysine max L.) genotypes evaluated under rainfed conditions of Kashmir Himalayas in India. J. Appl. Nat. Sci. 2015, 7, 910-915. [CrossRef]

31. Palmquist, D.L. The Role of Dietary Fats in Efficiency of Ruminants. J. Nutr. 1994, 124, 1377S-1382S.

32. Tukur, H.M.; Lallès, J.P.; Mathis, C.; Caugant, I.; Toullec, R. Digestion of soybean globulins, glycinin, $\alpha$-conglycinin and $\beta$-conglycinin in the preruminant and the ruminant calf. Can. J. Anim. Sci. 1993, 73, 891-905. [CrossRef]

33. Liener, I.E. Implications of antinutritional components in soybean foods. Crit. Rev. Food Sci. Nutr. 1994, 34, 31-67. [CrossRef]

34. Patra, A.K.; Saxena, J. The effect and mode of action of saponins on the microbial populations and fermentation in the rumen and ruminant production. Nutr. Res. Rev. 2009, 22, 204-219. [CrossRef] [PubMed]

35. Shiraiwa, M.; Harada, K.; Okubo, K. Composition and Content of Saponins in Soybean Seed According to Variety, Cultivation Year and Maturity. Agric. Biol. Chem. 1991, 55, 323-331.

36. Wang, B.; Ma, M.P.; Diao, Q.Y.; Tu, Y. Saponin-Induced Shifts in the Rumen Microbiome and Metabolome of Young Cattle. Front. Microbiol. 2019, 10, 356. [CrossRef] [PubMed]

37. Paek, N.C.; Sexton, P.J.; Naeve, S.L.; Shibles, R. Differential Accumulation of Soybean Seed Storage Protein Subunits in Response to Sulfur and Nitrogen Nutritional Sources. Plant Prod. Sci. 2000, 3, 268-274. [CrossRef] 
38. Arefrad, M.; Babaian Jelodar, N.; Nematzadeh, G.; Karimi, M.; Kazemitabar, S. Assessment of seed storage protein composition of six Iranian adopted soybean cultivars [Glycine max (L.) Merrill.]. J. Plant Mol. Breed. 2014, 2, 29-44.

39. Biel, W.; Gawęda, D.; Łysoń, E.; Hury, G. The effect of variety and agrotechnical factors on nutritive value of soybean seeds. Acta Agrophysica 2017, 24, 395-404.

40. de Barros, É.A.; Broetto, F.; Bressan, D.F.; Sartori, M.M.P.; Costa, V.E. Chemical composition and lipoxygenase activity in soybeans (Glycine max L. Merr.) submitted to gamma irradiation. Radiat. Phys. Chem. 2014, 98, 29-32. [CrossRef]

41. Kanai, M.; Yamada, T.; Hayashi, M.; Mano, S.; Nishimura, M. Soybean (Glycine max L.) triacylglycerol lipase GmSDP1 regulates the quality and quantity of seed oil. Sci. Rep. 2019, 9, 8924. [CrossRef]

42. Rechenmacher, C.; Wiebke-Strohm, B.; de Oliveira-Busatto, L.A.; Polacco, J.C.; Carlini, C.R.; Bodanese-Zanettini, M.H. Effect of soybean ureases on seed germination and plant development. Genet. Mol. Biol. 2017, 40, 209-216. [CrossRef]

43. Kania, J.; Zając, T.; Śliwa, J. Economic efficiency of soybean and rapeseed cultivation in western Poland. Ann. Pol. Assoc. Agric. Agribus. Econ. 2017, XVIII, 133-138.

44. Jerzak, M.; Mikulski, W. The importance of subsidies for the production of grain legumes for reconstruction of the domestic market of protein raw materials of vegetable origin in Poland. Probl. Agric. Econ. 2017, 2, 152-163.

45. Akbarian, A.; Khorvash, M.; Ghorbani, G.R.; Ghasemi, E.; Dehghan-Banadaky, M.; Shawrang, P.; Hosseini Ghaffari, M. Effects of roasting and electron beam irradiating on protein characteristics, ruminal degradability and intestinal digestibility of soybean and the performance of dairy cows. Livest. Sci. 2014, 168, 45-52. [CrossRef]

46. Dhiman, T.R.; Korevaar, A.C.; Satter, L.D. Particle Size of Roasted Soybeans and the Effect on Milk Production of Dairy Cows. J. Dairy Sci. 1997, 80, 1722-1727. [CrossRef]

47. Muya, M.C.; Nkosi, B.D.; Leeuw, K.J. Production response of dairy cows fed different dietary inclusion of cold- pressed soybean meal. Res. Opin. Anim. Vet. Sci. 2011, 1, 344-348.

48. Giallongo, F.; Oh, J.; Frederick, T.; Isenberg, B.; Kniffen, D.M.; Fabin, R.A.; Hristov, A.N. Extruded soybean meal increased feed intake and milk production in dairy cows. J. Dairy Sci. 2015, 98, 6471-6485. [CrossRef]

49. Spanghero, M.; Zanfi, C.; Signor, M.; Davanzo, D.; Volpe, V.; Venerus, S. Effects of plant vegetative stage and field drying time on chemical composition and in vitro ruminal degradation of forage soybean silage. Anim. Feed Sci. Technol. 2015, 200, 102-106. [CrossRef]

50. Gardinal, R.; Calomeni, G.D.; Zanferari, F.; Vendramini, T.H.A.; Takiya, C.S.; Del Valle, T.A.; Renno, F.P. Different durations of whole raw soybean supplementation during the prepartum period: Milk fatty acid profile and oocyte and embryo quality of early-lactating Holstein cows. J. Dairy Sci. 2018, 101, 675-689. [CrossRef]

51. Venturelli, B.C.; de Freitas Júnior, J.E.; Takiya, C.S.; de Araújo, A.P.C.; Santos, M.C.B.; Calomeni, G.D.; Gardinal, R.; Vendramini, T.H.A.; Rennó, F.P. Total tract nutrient digestion and milk fatty acid profile of dairy cows fed diets containing different levels of whole raw soya beans. J. Anim. Physiol. Anim. Nutr. 2015, 99, 1149-1160. [CrossRef]

52. Barletta, R.V.; Gandra, J.R.; Bettero, V.P.; Araújo, C.E.; Del Valle, T.A.; de Almeida, G.F.; Ferreira de Jesus, E.; Mingoti, R.D.; Benevento, B.C.; de Freitas Júnior, J.E.; et al. Ruminal biohydrogenation and abomasal flow of fatty acids in lactating cows: Oilseed provides ruminal protection for fatty acids. Anim. Feed Sci. Technol. 2016, 219, 111-121. [CrossRef]

53. Naves, A.B.; Freitas Júnior, J.E.; Barletta, R.V.; Gandra, J.R.; Calomeni, G.D.; Gardinal, R.; Takiya, C.S.; Vendramini, T.H.A.; Mingoti, R.D.; Rennó, F.P. Effect of raw soya bean particle size on productive performance and digestion of dairy cows. J. Anim. Physiol. Anim. Nutr. 2016, 100, 778-788. [CrossRef]

54. Vargas-Bello-Pérez, E.; Mustafa, A.F.; Seguin, P. Effects of Feeding Forage Soybean Silage on Milk Production, Nutrient Digestion, and Ruminal Fermentation of Lactating Dairy Cows. J. Dairy Sci. 2008, 91, 229-235. [CrossRef] [PubMed]

55. Faldet, M.A.; Son, Y.S.; Satter, L.D. Chemical, in vitro, and in vivo Evaluation of Soybeans Heat-Treated by Various Processing Methods. J. Dairy Sci. 1992, 75, 789-795. [CrossRef] 
56. Arelovich, H.M.; Lagrange, S.; Torre, R.; Martinez, M.F.; Laborde, H.E. Feeding value of whole raw soya beans as a protein supplement for beef cattle consuming low-quality forages. J. Anim. Physiol. Anim. Nutr. 2018, 102, e421-e430. [CrossRef]

57. Freitas, J.E.; Takiya, C.S.; Del Valle, T.A.; Barletta, R.V.; Venturelli, B.C.; Vendramini, T.H.A.; Mingoti, R.D.; Calomeni, G.D.; Gardinal, R.; Gandra, J.R.; et al. Ruminal biohydrogenation and abomasal flow of fatty acids in lactating cows fed diets supplemented with soybean oil, whole soybeans, or calcium salts of fatty acids. J. Dairy Sci. 2018, 101, 7881-7891. [CrossRef] [PubMed]

58. Prabakaran, M.; Lee, K.-J.; An, Y.; Kwon, C.; Kim, S.; Yang, Y.; Ahmad, A.; Kim, S.-H.; Chung, I.-M. Changes in Soybean (Glycine max L.) Flour Fatty-Acid Content Based on Storage Temperature and Duration. Molecules 2018, 23, 2713. [CrossRef]

59. Cheng, M.-H.; Rosentrater, K.A. Techno-Economic Analysis of Extruding-Expelling of Soybeans to Produce Oil and Meal. Agriculture 2019, 9, 87. [CrossRef]

60. Liu, Y.; Ren, X.; Wu, H.; Meng, Q.; Zhou, Z. Steam Explosion Treatment of Byproduct Feedstuffs for Potential Use as Ruminant Feed. Animals 2019, 9, 688. [CrossRef]

61. Borhan, M.; Snyder, H.E. Lipoxygenase destruction in whole soybeans by combinations of heating and soaking in ethanol. J. Food Sci. 1979, 44, 586-590. [CrossRef]

62. Baker, E.C.; Mustakas, G.C. Heat inactivation of trypsin inhibitor, lipoxygenase and urease in soybeans: Effect of acid and base additives. J. Am. Oil Chem. Soc. 1973, 50, 137-141. [CrossRef]

63. Rafiee-Yarandi, H.; Alikhani, M.; Ghorbani, G.; Sadeghi-Sefidmazgi, A. Effects of temperature, heating time and particle size on values of rumen undegradable protein of roasted soybean. S. Afr. J. Anim. Sci. 2016, 46, 170-179. [CrossRef]

64. Tice, E.M.; Eastridge, M.L.; Firkins, J.L. Raw Soybeans and Roasted Soybeans of Different Particle Sizes. 2. Fatty Acid Utilization by Lactating Cows. J. Dairy Sci. 1994, 77, 166-180. [CrossRef]

65. Salles, M.; D’Abreu, L.; Júnior, L.; César, M.; Guimarães, J.; Segura, J.; Rodrigues, C.; Zanetti, M.; Pfrimer, K.; Netto, A. Inclusion of Sunflower Oil in the Bovine Diet Improves Milk Nutritional Profile. Nutrients 2019, 11, 481. [CrossRef] [PubMed]

66. Reddy, P.V.; Morrill, J.L.; Nagaraja, T.G. Release of Free Fatty Acids from Raw of Processed Soybeans and Subsequent Effects on Fiber Digestibilities. J. Dairy Sci. 1994, 77, 3410-3416. [CrossRef]

67. Zhang, Q.; Su, H.; Wang, F.; Cao, Z.; Li, S. Effects of energy density in close-up diets and postpartum supplementation of extruded full-fat soybean on lactation performance and metabolic and hormonal status of dairy cows. J. Dairy Sci. 2015, 98, 7115-7130. [CrossRef] [PubMed]

68. Harper, M.T.; Oh, J.; Melgar, A.; Nedelkov, K.; Räisänen, S.; Chen, X.; Martins, C.M.M.R.; Young, M.; Ott, T.L.; Kniffen, D.M.; et al. Production effects of feeding extruded soybean meal to early-lactation dairy cows. J. Dairy Sci. 2019, 102, 8999-9016. [CrossRef]

69. Kazemi-Bonchenari, M.; Alizadeh, A.R.; Tahriri, A.R.; Karkoodi, K.; Jalali, S.; Sadri, H. The Effects of Partial Replacement of Soybean Meal by Xylose-Treated Soybean Meal in the Starter Concentrate on Performance, Health Status, and Blood Metabolites of Holstein Calves. Ital. J. Anim. Sci. 2015, 14, 3680. [CrossRef]

70. ZeidAli-Nejad, A.; Ghorbani, G.R.; Kargar, S.; Sadeghi-Sefidmazgi, A.; Pezeshki, A.; Ghaffari, M.H. Nutrient intake, rumen fermentation and growth performance of dairy calves fed extruded full-fat soybean as a replacement for soybean meal. Animal 2018, 12, 733-740. [CrossRef]

71. Asekova, S.; Shannon, J.G.; Lee, J.-D. The Current Status of Forage Soybean. Plant Breed. Biotechnol. 2014, 2, 334-341. [CrossRef]

72. Darmosarkoro, W.; Harbur, M.M.; Buxton, D.R.; Moore, K.J.; Devine, T.E.; Anderson, I.C. Growth, Development, and Yield of Soybean Lines Developed for Forage. Agron. J. 2001, 93, 1028-1034. [CrossRef]

(C) 2020 by the authors. Licensee MDPI, Basel, Switzerland. This article is an open access article distributed under the terms and conditions of the Creative Commons Attribution (CC BY) license (http://creativecommons.org/licenses/by/4.0/). 